\title{
The Importance of Computer Games Development in the Computing Curriculum in Schools
}

\author{
Dave Renton ${ }^{1}$
}

Published online: 10 December 2015

(C) Springer Science+Business Media New York 2015

I have been teaching computer games development to students in further education for over 9 years. I commenced my teaching career in what was originally Reid Kerr College, but which during the past 3 years has been West College Scotland [formed as a merger of Reid Kerr, Clydebank and James Watt (Inverclyde) colleges]. During the past 5 years I have also been involved with Microsoft as a Microsoft Innovative Expert Educator, and during the past 3 years I have been using Microsoft MVP for Kinect. My links with Microsoft are the result of the work I have done, both in my own time and for funded projects in relation to Games in Education. During this time I have created a number of educational games using Xbox 360 controllers and Kinect. However, during these past few years, Microsoft have taken a genuine interest in the way that I use games development to teach programming, which in turn is linked to Computer Science, and which in turn is replacing traditional computing in schools throughout the UK. I should add that this is a positive change, and one that Microsoft is very keen to promote and be a part of. For several years, computing classes in high schools have revolved around Microsoft Office, but these are now being replaced with computational thinking and programming, skills that "Computing" teachers do not necessarily possess.

During this time, I have learned a few things about games development, particularly its role within education. First of all, I think that there is no better way in which to engage students of all ages in computer science, especially programming, than by teaching them games development. Second, we still have a real problem in trying to attract women to study and work in computing, and this is

Dave Renton

david.renton@wcs.ac.uk

1 West College Scotland, Paisley Campus: Renfrew Road, Paisley, Renfrewshire PA3 4DR, Scotland, UK 
particularly the case with games development. Third, students need to understand that games development is not an easy option-we do not sit and play games all day with our students (well, not all the time). I think that the approach that can be used to address all three of these issues is to encourage schoolchildren (as young as possible) to take an interest in and learn about computer science and games development.

In this piece I wish to consider the case of Scotland, where this has in theory been recognised. Just look at the experiences and outcomes detailed in the Scottish Government's Curriculum for Excellence (shown in the Fig. 1). Schoolchildren are supposed to be studying and even creating computer games from second level (children aged 8 or 9). At the third and fourth levels, they should be creating their own games in high school. In January 2016, the BBC will be getting on-board with this by issuing a million wearable, programmable Microbit computers to 11-yearold and 12-year-old schoolchildren throughout the UK in an apparently arbitrary effort to encourage this agenda. However, teachers need help; they need to develop pedagogical approaches for teaching programming and games development, and they need training in the different tools and languages that can be used.

I always tell my students that a good programmer can program anything, and that programming games can be more challenging than other types of programming projects that students are given to work on. They may not all go on to work in the games industry, but those who can really grasp computational thinking and who know how to apply it in code, should in most cases find a job at the end of the rainbow, since in Scotland and throughout the UK in general, there are a shortage of good programmers, and jobs are going unfilled. I recently spoke with the representatives of a local company, who told me they have never managed to fill all the programming positions they have with good coders. This shortage has even been acknowledged by the Scottish government, which has recently set up a Digital

\begin{tabular}{|c|c|c|c|}
\hline Early & Second & Third & Fourth \\
\hline $\begin{array}{l}\text { I am developing problem-solving strategies, navigation and } \\
\text { co-ordination skills, as I play and learn with electronic games, } \\
\text { remote control or programmable toys. } \\
\text { TCH 0-09a/ TCH 1-09a }\end{array}$ & $\begin{array}{l}\text { Using appropriate software, I } \\
\text { can work collaboratively to } \\
\text { design an interesting and } \\
\text { entertaining game which } \\
\text { incorporates a form of control } \\
\text { technology or interactive } \\
\text { multimedia. } \\
\qquad \text { TCH 2-09a }\end{array}$ & $\begin{array}{l}\text { Using appropriate software, I } \\
\text { can work individually or } \\
\text { collaboratively to design and } \\
\text { implement a game, } \\
\text { animation or other } \\
\text { application. }\end{array}$ & $\begin{array}{l}\text { By learning the basic } \\
\text { principles of a programming } \\
\text { language or control } \\
\text { technology, I can design a } \\
\text { solution to a scenario, } \\
\text { implement it and evaluate its } \\
\text { success. } \\
\qquad \text { TCH 4-09a } \\
\text { I can create graphics and } \\
\text { animations using appropriate } \\
\text { software which utilise my } \\
\text { skills and knowledge of the } \\
\text { application. } \\
\text { I can use features of } \\
\text { software to create my own } \\
\text { animation which can then be } \\
\text { used to create an animated } \\
\text { sequence. }\end{array}$ \\
\hline
\end{tabular}

Fig. 1 Computer science learning outcomes in the Curriculum for Excellence (Scottish Government, 2004) 
Skills Academy to try and redress this problem (Scottish Government, 2015). There is a great need for programmers. However, introducing high school pupils to programming by teaching Visual Basic and by getting them to create a simple business type application for entering data are not the best ways to engage them. Games development is a great topic, since it not only helps to foster the necessary coding skills in school pupils, but also allows them to put other skillsets from other subjects into practice, for instance, by creating art and music for their games. Therefore, games development could be a critical means through which both male and female school pupils can acquire an aptitude in Computer Science.

I currently have 108 college students studying games development at various levels, 5 of whom are female. I have another 43 S5/S6 (ages 16-18) school students studying for the National Progression Award in Games Development who travel from schools in Renfrewshire and East Renfrewshire to my classes twice a week. In that group there are 6 girls, which is still a poor, albeit a better, ratio; and herein lies a clue. We used to blame this on the fact that only boys play computer games, and therefore only boys want to design games. However, in the last couple of years this perception has changed, and females are now in the majority among gamers on mobile devices. So bang goes that theory! The problem seems to arise during 3rd or 4th year at high school when pupils choose their subjects; the number of girls who choose Computing is very low, which in turn leads to low numbers of girls applying for FE and HE courses in Computing at college and university level.

Schoolchildren should be introduced to computing subjects at as young an age as possible, and-this is my third point-students need to realise that games development is not an easy option. In fact, I would argue that of the 3 courses we run at WCS (which are Software Development, Technical Support and Games Development), Games Development is the most difficult and challenging course. For most students, the mathematics and programming units are the most challenging, since those are the 2 units that the majority of students fail, drop out from, or struggle with.

One of my suggestions is that computer games development should be treated as a cross-curricular topic (as per the Curriculum for Excellence) in secondary schools and perhaps even primary schools, which is used to engage learners in traditional subjects like mathematics, physics, English, music, and art, in addition to computing and ICT. Some of these subjects are ones from which male pupils in particular have been disengaging in recent years, and so games development classes could help address a different imbalance. I also think that by studying games development from a young age, female pupils will be more likely to consider computing as a real career choice.

A few years ago, Valve made their popular puzzle game Portal free as they wanted teachers to play it and understand how much potential it has in educating young students in subjects like physics. Valve are quoted as saying (Develop, 2011a),

"It's eye-opening to see how video games can be used in amazing and unexpected ways to help educate our next generation." 
"Using interactive tools like the Portal series to draw them in makes physics, maths, logic, spatial reasoning, probability, and problem-solving interesting, cool, and fun which gets us one step closer to our goal-engaged, thoughtful kids."

In 2011, NESTA collaborated with industry luminaries Alex Hope and Ian Livingstone to publish Next Gen-a widely-applauded government advice paper on how to improve games education (Develop, 2011b). This report contained some interesting recommendations:

- Teachers should use video games and visual effects at school to draw greater numbers of young people into studying STEM (Science, Technology, Engineering and Mathematics) subjects and computer science.

- Art and computer science should be included in the English Baccalaureate.

- Schools should encourage art-tech crossovers and work-based learning through school clubs.

- A new national video games development and animation competition for schools should be introduced.

Education Scotland (2011) also recognised this:

"Game Design is a creative medium. It challenges pupils to analyse problems, structure solutions and continuously evaluate their progress. There are many game design tools available for use in schools and at home. It can be used in a number of different ways in our curriculum - not just within computing classrooms."

I believe that schools should use games development as an integrated learning context to support the Curriculum for Excellence. Games development is an ideal topic for a joined-up learning approach that is an integral feature of this framework. Games development involves computer programming, physics, mathematics, English, music, art, and even entrepreneurship. It might be thought that games development is $90 \%$ programming, but although programming is a vital part of games, there are so many other curricular areas involved.

I think that the future for games development in Scotland can be a bright one, but we do have to look at the way in which the relevant skills are taught from primary school level right up to university level. Games are a great hook with which to engage schoolchildren, but we need to start making students think through the solutions to problems logically (i.e. computational thinking), and learn how to implement those solutions in code from an early age. We need to make female students more aware of this before they choose their subjects in high school, that games development is a valid career path for them. Finally, we must make students and parents realise that computer games is a serious industry, which provides jobs and revenue to the Scottish economy. 


\section{References}

Develop. (2011a). Portal goes free in Valve education push. http://www.develop-online.net/news/38654/ Portal-goes-free-in-Valve-education-push.

Develop. (2011b). How to revolutionise games education in 20 steps. http://www.develop-online.net/ analysis/how-to-revolutionise-games-education-in-20-steps/0116949. Accessed 13 Nov 2015.

Learning and Teaching Scotland. (2011). Game design and learning. http://www.ltscotland.org.uk/ usingglowandict/gamesbasedlearning/gamedesign/gamedesignandlearning.asp. Accessed 13 Nov 2015.

Scottish Government. (2004). Curriculum for Excellence. http://www.educationscotland.gov.uk/ learningandteaching/thecurriculum/whatiscurriculumforexcellence/index.asp.

Scottish Government. (2015). 'Scotland's first digital skills academy opens its doors' 13 October 2015. http://news.scotland.gov.uk/news/scotland-s-first-digital-skills-academy-opens-its-doors-1e48.aspx. Accessed 13 Nov 2015. 